\title{
Packaging Other
}

National Cancer Institute

\section{Source}

National Cancer Institute. Packaging Other. NCI Thesaurus. Code C113034.

Any packaging operation not elsewhere described. 